University of Nebraska - Lincoln

DigitalCommons@University of Nebraska - Lincoln

Nebraska Cooperative Fish \& Wildlife Research Nebraska Cooperative Fish \& Wildlife Research Unit -- Staff Publications

2004

\title{
Age-specific patterns in density-dependent growth of white crappie, Pomoxis annularis
}

\author{
K. L. Pope \\ Texas Tech University, kpope2@unl.edu \\ G. R. Wilde \\ Texas Tech University \\ B. W. Durham \\ Texas Tech University
}

Follow this and additional works at: https://digitalcommons.unl.edu/ncfwrustaff

Part of the Other Environmental Sciences Commons

Pope, K. L.; Wilde, G. R.; and Durham, B. W., "Age-specific patterns in density-dependent growth of white crappie, Pomoxis annularis" (2004). Nebraska Cooperative Fish \& Wildlife Research Unit -- Staff Publications. 71.

https://digitalcommons.unl.edu/ncfwrustaff/71

This Article is brought to you for free and open access by the Nebraska Cooperative Fish \& Wildlife Research Unit at DigitalCommons@University of Nebraska - Lincoln. It has been accepted for inclusion in Nebraska Cooperative Fish \& Wildlife Research Unit -- Staff Publications by an authorized administrator of DigitalCommons@University of Nebraska - Lincoln. 


\title{
Age-specific patterns in density-dependent growth of white crappie, Pomoxis annularis
}

\author{
K. L. POPE, G. R. WILDE \& B. W. DURHAM \\ Wildlife and Fisheries Management Institute, Texas Tech University, Lubbock, TX, USA
}

\begin{abstract}
The relationship between growth in white crappie, Pomoxis annularis Rafinesque, and climate, lake morphometry and population density was studied in 103 Texas reservoirs. Growth of age-0 through age- 3 white crappie was significantly $(P \leq 0.05)$ related to latitude, growing season and surface area. Growth of age-1 through age-5 white crappie also was related to annual precipitation. Multiple linear regression models with precipitation and mean catch per unit effort (CPUE) of white crappie as independent variables explained $14-22 \%$ of the variation in growth of age- $0,-1$ and -2 white crappie. By contrast, growth of age- $3,-4$ and -5 white crappie was unrelated to CPUE. Apparently, between age 2 and 3, the density of white crappie in Texas reservoirs falls below a density-dependent growth threshold beyond which growth is no longer related to density. This density-dependent threshold was most likely related to angler harvest of larger, older white crappie.
\end{abstract}

KEYWORDS: angling, length, population dynamics, Pomoxis annularis.

\section{Introduction}

Density-dependent growth is commonly observed in fishes (e.g. Le Cren 1958; Backiel \& Le Cren 1978; Walters \& Post 1993; Byström \& García-Berthou 1999). As species density increases, growth of individual fish slows as a result of increased intraspecific competition. Size at maturity and maximum size of individual fish in a given population are directly related to individual growth rates, with smaller maturation and maximum sizes observed in slower growing fish (Bowen, D'Angelo, Arnold, Keniry \& Albrecht 1991; Walters \& Post 1993). However, the exact relationship between growth and population density is not clearly understood and probably varies amongst species. Walters \& Post (1993) argued that species-specific density-growth formulae are needed to understand better the mechanisms, and population- and community-level consequences of density-dependent growth.

Crappie, Pomoxis spp., are common in lakes and reservoirs throughout North America (Lee, Gilbert, Hocutt, Jenkins, McAllister \& Stauffer 1980) and have a propensity for overpopulation, especially in small water bodies (Mitzner 1984) or those without adequate densities of limnetic predators (Cichra, Noble \& Farquhar 1984; Gabelhouse 1984; Summers, Boxrucker \& Gabelhouse 1994). Overpopulation may reduce growth rates of individual crappie because of increased intraspecific competition. From a fishery perspective, crappie populations with abundant small, slow growing fish provide little value to recreational anglers. Thus, management of crappie populations typically is directed toward maintaining reduced crappie densities and large prey densities (Gabelhouse 1984). From an ecological perspective, populations of slow-growing crappie compete with larvae and juveniles of other fishes for zooplankton (Guest, Drenner, Threlkeld, Martin \& Smith 1990; Pope \& DeVries 1994).

Growth of crappie is also strongly influenced by abiotic factors, especially temperature (Hayward \& Arnold 1996). Thus, the effect of abiotic factors on growth must be accounted for (or controlled) to assess adequately density-dependent growth of white crappie on broad scales. In this paper, variation in growth of age- 0 to age- 5 white crappie, $P$. annularis Rafinesque, in 103 Texas reservoirs is related to crappie density after climate-related effects (i.e. geographical location of reservoirs) were controlled. 


\section{Materials and methods}

White crappie were collected from 118 Texas reservoirs using trap (modified fyke) nets in the course of routine autumn (August to December) sampling during 19751993. Scales or otoliths from a subsample of fish from each reservoir were removed for age and growth analyses. Scale impressions were made on acetate slides and fish were aged by counting annular marks. When otoliths were used, age was determined by counting annular marks on whole or sectioned otoliths under low magnification. The unweighted mean white crappie length-at-capture for age $0,1,2,3,4$ and 5, across years for each reservoir was calculated. Only those reservoir-age group combinations with at least 10 age estimates were retained for analyses. This resulted in a final sample of 103 reservoirs located throughout Texas.

Linear and multiple regressions were used to assess the nature and strength of relationships between growth (mean length-at-capture for age 0, 1, 2, 3, 4 and 5), density and three climate-related and four morphoedaphic variables. White crappie density was indexed using catch per unit effort (CPUE; total number of white crappie per trap-net night) averaged across the same period used to collect age and growth information. Climate-related variables included latitude, annual precipitation and growing-season length (number of frost-free days in the year). In Texas, aridity and elevation decrease from north-west to south-east in the state, whereas growing season increases from north to south, as expected from latitudinal variation in solar insolation, and from west to east with the gradual decrease in elevation (Miranda \& Durocher 1986; Ground \& Groeger 1994; Wilde \&
Muoneke 2001). Morphoedaphic variables included surface area (ha), mean and maximum depth (m), and water conductivity $\left(\mu \mathrm{S} \mathrm{cm}^{-1}\right)$. Precipitation and growing season length for each reservoir were obtained from Ramos (1995). Latitude and morphoedaphic information were obtained from the Texas Parks and Wildlife Department's Lake Categorization File, a database of morphometric and biological characteristics of Texas reservoirs. Based on previous studies of fish growth and production, white crappie growth was expected to be positively related to precipitation, growing-season length, surface area, depth (mean and maximum) and water conductivity, and negatively to latitude and density. Statistical significance was set at $\alpha=0.05$, but for correlations was adjusted using the sequential Bonferroni technique (Miller 1981; Rice 1989) within each age group to control the probability of incorrectly rejecting one or more true null hypotheses. This adjustment was needed because multiple simultaneous correlations were conducted within each age group.

\section{Results}

Across all study reservoirs, mean \pm SE total lengths at capture (and ranges) of white crappie were: age $0=115 \pm 3 \mathrm{~mm}(77-176 \mathrm{~mm}) ;$ age $1=186 \pm 4 \mathrm{~mm}$ $(102-259 \mathrm{~mm})$; age $2=233 \pm 4 \mathrm{~mm}(152-321 \mathrm{~mm})$; age $3=267 \pm 4 \mathrm{~mm}(153-351 \mathrm{~mm}) ;$ age $4=286 \pm$ $4 \mathrm{~mm} \quad(187-359 \mathrm{~mm}) ;$ and age $5=301 \pm 8 \mathrm{~mm}$ (212-368 mm). Inspection of scatter plots of white crappie growth versus each independent variable indicated these relationships generally were linear. Growth of age-0 through age-3 white crappie was related negatively $(P \leq 0.05)$ to latitude and positively to growing season length (Table 1). Growth of age-1

Table 1. Minima and maxima for three climate-related variables, four morphoedaphic variables and white crappie density [indexed with catch per unit effort (CPUE)], number of reservoirs $(n)$ and correlation coefficients $(r)$ for relationships between lengths of age- $0,-1,-2,-3,-4$ and -5 white crappie and climate-related, morphoedaphic, and density variables in Texas reservoirs

\begin{tabular}{|c|c|c|c|c|c|c|c|c|c|c|c|c|c|c|}
\hline & \multirow[b]{3}{*}{ Min } & \multirow[b]{3}{*}{ Max } & \multicolumn{12}{|c|}{ Age } \\
\hline & & & \multicolumn{2}{|r|}{0} & \multicolumn{2}{|r|}{1} & \multicolumn{2}{|r|}{2} & \multicolumn{2}{|r|}{3} & \multicolumn{2}{|r|}{4} & \multicolumn{2}{|r|}{5} \\
\hline & & & $n$ & $r$ & $n$ & $r$ & $n$ & $r$ & $n$ & $r$ & $n$ & $r$ & $n$ & $r$ \\
\hline Latitude & 27 & 35 & 76 & $-0.42 * *$ & 96 & $-0.30 * *$ & 103 & $-0.35^{* *}$ & 91 & $-0.26^{*}$ & 59 & $-0.27 *$ & 21 & -0.18 \\
\hline Precipitation $(\mathrm{cm})$ & 48 & 138 & 77 & $0.23 *$ & 96 & $0.33 * *$ & 103 & $0.36^{* *}$ & 91 & $0.38 * *$ & 59 & $0.40 * *$ & 21 & $0.66^{* *}$ \\
\hline Growing season (days) & 187 & 322 & 77 & $0.37 * *$ & 96 & $0.33 * *$ & 103 & $0.34 * *$ & 91 & $0.28 * *$ & 59 & 0.08 & 21 & $0.45^{*}$ \\
\hline Area (ha) & 5 & 90000 & 76 & $0.28 *$ & 96 & $0.39 * *$ & 103 & $0.42 * *$ & 91 & $0.36^{* *}$ & 59 & $0.27 *$ & 21 & 0.37 \\
\hline Mean depth (m) & 2 & 46 & 72 & 0.08 & 88 & 0.21 & 93 & 0.17 & 83 & 0.15 & 52 & 0.08 & 17 & -0.37 \\
\hline Maximum depth (m) & 6 & 152 & 76 & 0.07 & 94 & $0.27 * *$ & 100 & $0.26^{* *}$ & 88 & 0.21 & 57 & 0.14 & 20 & -0.04 \\
\hline Conductivity $\left(\mu \mathrm{S} \mathrm{cm}^{-1}\right)$ & 75 & 5500 & 74 & -0.20 & 92 & -0.07 & 98 & -0.06 & 86 & -0.12 & 56 & -0.01 & 19 & 0.11 \\
\hline $\begin{array}{l}\text { Mean CPUE } \\
\quad(\text { number net night }\end{array}$ & 1 & 139 & 75 & $-0.29 *$ & 93 & $-0.35 * *$ & 100 & $-0.26^{* *}$ & 88 & -0.12 & 57 & -0.10 & 20 & 0.01 \\
\hline
\end{tabular}

${ }^{*} P \leq 0.05 ; * * P \leq 0.05$ based on the sequential Bonferroni technique. 
through age- 5 white crappie also was positively related to annual precipitation (Table 1). Amongst these three climatic variables, precipitation was the best overall predictor of growth and explained $5-44 \%$ of the variation in growth of white crappie. Age-1 through age-3 white crappie growth was positively related to reservoir surface area, whereas white crappie growth was generally unrelated to water depth (mean and maximum) and conductivity (Table 1 ).

Growth of age- $0,-1$ and -2 white crappie was inversely related $(P \leq 0.01)$ to crappie CPUE, which explained $7-12 \%$ of variation in growth (Table 1 ; Fig. 1). However, growth of age-3, -4 and -5 white crappie was unrelated $(P>0.27)$ to CPUE.

Multiple linear regression models: age- 0 : length $=$ $98.020+0.287$ precipitation -0.266 CPUE; $R^{2}=0.141$,

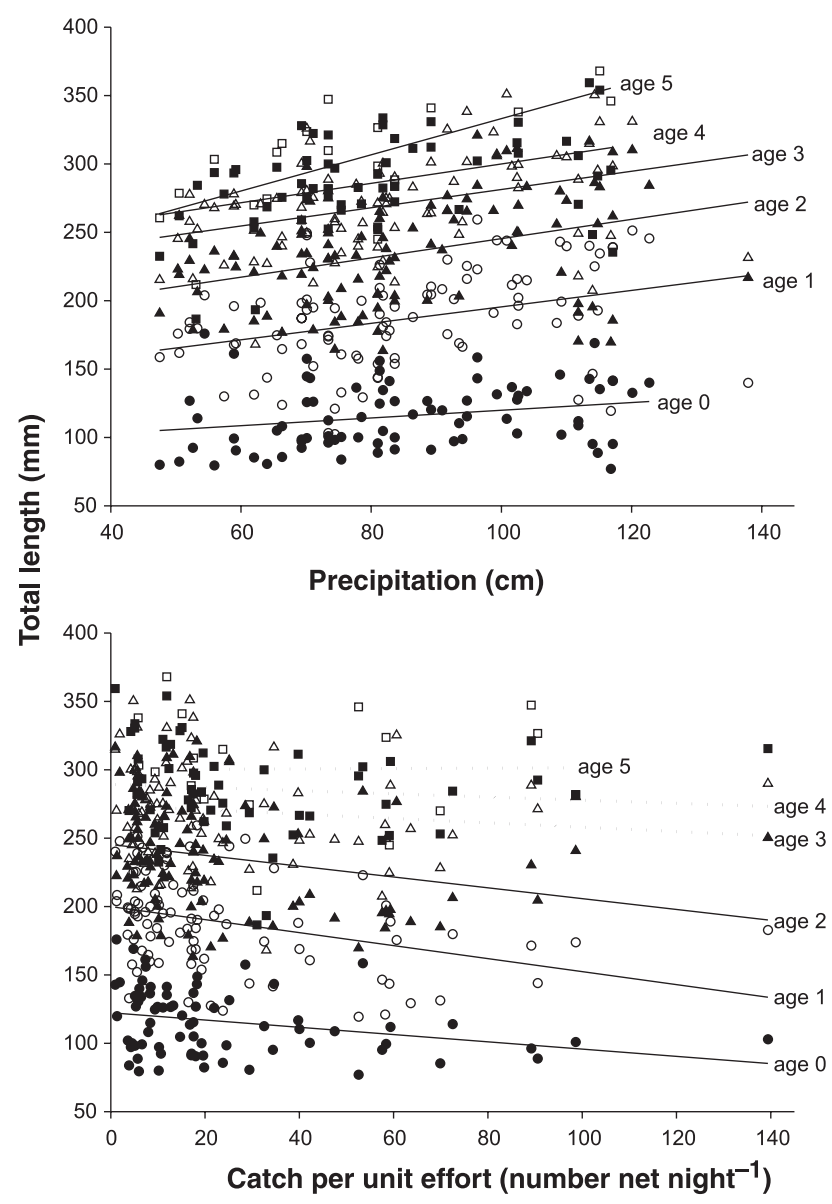

Figure 1. Relationships of mean length-at-capture (mm) with annual precipitation $(\mathrm{cm})$ and density (catch per unit effort; number trap-net night $^{-1}$ ) in Texas populations of age-0 (○), -1 (○), $-2(\mathbf{\Delta}),-3(\triangle),-4(\mathbb{\square})$, and $-5(\square)$ white crappie. Significant $(P \leq 0.04)$ relationships are illustrated with solid lines; non-significant $(P>0.27)$ relationships are illustrated with dotted lines. $n=74, P=0.004 ;$ age- 1 : length $=153.795+0.535$ precipitation -0.458 CPUE; $R^{2}=0.217, \quad n=91$, $P<0.0001 ;$ and age- 2 : length $=188.681+0.670$ precipitation - 0.394 CPUE; $R^{2}=0.195, \quad n=98$, $P<0.0001$, for precipitation and mean CPUE of age$0,-1$, and -2 white crappie were significant predictors of white crappie growth. These models explained $14-22 \%$ of the variation in growth of white crappie. For ages 3,4 and 5, CPUE was not a significant $(P>0.18)$ variable in multiple linear regression models.

\section{Discussion}

Indirect measures of lake productivity such as total dissolved solids, morphoedaphic index, turbidity, reservoir age, surface area, and mean and maximum depth generally are fair predictors of fish biomass (Ryder 1965; Jenkins \& Morais 1971; Oglesby 1977), recruitment (Mitzner 1991; Guy \& Willis 1995) and growth (Miranda \& Durocher 1986; McInerny \& Cross 1999; Tomcko \& Pierce 2001; Wilde \& Muoneke 2001). As expected, white crappie growth was positively related to precipitation, growing-season length and reservoir surface area, and negatively to latitude. Contrary to a priori predictions, white crappie growth was not related to water conductivity and depth. Precipitation was the best predictor of growth and explained $5-44 \%$ of the variation in growth of white crappie; however, residual variation was large in all age groups. Because of small sample sizes in several reservoirs, samples were pooled across years for each age group in each reservoir. Therefore, interannual variation in environmental conditions such as temperature (Siefert 1968; Pope, Willis \& Lucchesi 1996; Pine \& Allen 2001), water level (Mitzner 1981; Beam 1983; Maceina \& Stimpert 1998; Sammons, Bettoli \& Greear 2001), food availability (Sammons et al. 2001) and predator density (Cichra et al. 1984; Gabelhouse 1984; Boxrucker 1987) that affect recruitment and growth of white crappie were unaccounted for in the present analyses. Variation amongst reservoirs in productivity, prey availability and angler exploitation rates (Miranda \& Durocher 1986; Dolman 1990; Muoneke 1994; Texas Parks and Wildlife Department, unpublished data) may also have contributed to the large residual variance.

Population density regulates early (age 0,1 and 2) growth of white crappie in Texas reservoirs. Previous studies (Guy \& Willis 1995; Pope \& Willis 1998; McInerny \& Cross 1999; Galinat, Willis, Blackwell \& Hubers 2002) documented inverse relationships between crappie density and growth. The present 
study, however, is the first to document age-specific effects of density on white crappie growth. Apparently, between age 2 and 3, white crappie growth in Texas reservoirs is no longer constrained by a densitydependent mechanism.

Fishing mortality is the most probable mechanism causing the decline in white crappie density below the growth-regulating threshold. Schoffman (1965) suggested that substantial angler harvest of white crappie could cause low crappie densities. Prior to 1985, no harvest limits existed for crappie in Texas waters. Positive results from an experimental length and bag limit on white crappie led to enactment of a $25.4-\mathrm{cm}$ statewide minimum-length limit for crappie in September 1990 (Webb \& Ott 1991). This minimum-length limit likely had little affect on the present assessment because no limit existed for most years. Prior to the minimum-length limit, anglers harvested white crappie $=20-25 \mathrm{~cm}$ (Webb \& Ott 1991). It is speculated that white crappie become acceptable to Texas anglers and, thus, vulnerable to exploitation at a length attained during their third or fourth year of life, the age at which white crappie growth ceases to be densitydependent.

\section{Management implications}

White crappie growth rates in the first couple of years of life are density-dependent. Reduction of white crappie density, especially of younger age groups, should result in faster growth rates of surviving crappie. Several authors have discussed methods for reducing density of young crappie and limiting recruitment to increase crappie growth rates (Cichra et al. 1984; Gabelhouse 1984; Boxrucker 1987; Summers et al. 1994). However, the potential negative effects of length limits on crappie growth rates have received little attention (but see Colvin 1991; Webb \& Ott 1991; Allen \& Miranda 1995; Hale, Lundquist, Miller \& Petering 1999). Implementing restrictive length limits on white crappie populations could lead to longer periods of density-dependent growth. In crowded white crappie populations, longer periods of reduced growth rates might result in smaller maximum size and reduced production of crappie, which may affect angler satisfaction (Allen \& Miranda 1996; Costello \& Betsill 1996). However, management biologists may encounter political pressure to maintain or establish crappie length limits, as some anglers favour crappie length limits even when positive results, such as increased size and age structure, are not evident (Allen \& Miranda 1996; Bister, Baker \& Willis 2000).

\section{Acknowledgments}

We gratefully acknowledge the efforts of Texas Parks and Wildlife Department Inland Fisheries staff that participated in collection of the data reported herein. We thank C. Chizinski, R. W. Luebke, and B. Van Zee for commenting on the manuscript. This is manuscript number T-9-950 of the College of Agricultural Sciences and Natural Resources, Texas Tech University.

\section{References}

Allen M.S. \& Miranda L.E. (1995) An evaluation of the value of harvest restrictions in managing crappie fisheries. North American Journal of Fisheries Management 15, 766-772.

Allen M.S. \& Miranda L.E. (1996) A qualitative evaluation of specialization among crappie anglers. In: L.E. Miranda \& D.R. DeVries (eds) Multidimensional Approaches to Reservoir Fisheries Management. Bethesda, MD: American Fisheries Society Symposium 16, pp. 145-151.

Backiel T. \& Le Cren E.D. (1978) Some density relationships for fish population parameters. In: S.D. Gerking (ed.) The Ecology of Freshwater Fish Production. Oxford: Blackwell Scientific Publications, pp. 279-302.

Beam J.H. (1983) The effect of annual water level management on population trends of white crappie in Elk City Reservoir, Kansas. North American Journal of Fisheries Management 3, 34-40.

Bister T.J., Baker B.M. \& Willis D.W. (2000) Angler opinions regarding fishing success and crappie regulations in a small South Dakota impoundment. Proceedings of the South Dakota Academy of Science 79, 11-19.

Bowen S.H., D’Angelo D.J., Arnold S.H., Keniry M.J. \& Albrecht R.J. (1991) Density-dependent maturation, growth, and female dominance in Lake Superior lake herring (Coregonus artedii). Canadian Journal of Fisheries and Aquatic Sciences 48, 569-576.

Boxrucker J. (1987) Largemouth bass influence on size structure of crappie populations in small Oklahoma impoundments. North American Journal of Fisheries Management 7, 273-278.

Byström P. \& García-Berthou E. (1999) Density dependent growth and size specific competitive interactions in young fish. Oikos 86, 217-232.

Cichra C.E., Noble R.L. \& Farquhar B.W. (1984) Relationships of white crappie populations to largemouth bass and bluegill. Proceedings of the Annual Conference of the Southeastern Association of Fish and Wildlife Agencies 35, 416-423.

Colvin M.A. (1991) Evaluation of minimum-size limits and reduced daily limits on the crappie populations and fisheries in five large Missouri reservoirs. North American Journal of Fisheries Management 11, 585-597. 
Costello M.E. \& Betsill R.K. (1996) Factors affecting angler fishing success ratings at fifteen Texas reservoirs, 19841993. In: L.E. Miranda \& D.R. DeVries (eds) Multidimensional Approaches to Reservoir Fisheries Management. Bethesda, MD: American Fisheries Society Symposium 16, pp. 277-282.

Dolman W.B. (1990) Classification of Texas reservoirs in relation to limnology and fish community associations. Transactions of the American Fisheries Society 119, 511520.

Gabelhouse D.W. Jr. (1984) An assessment of crappie stocks in small midwestern private impoundments. North American Journal of Fisheries Management 4, 371384.

Galinat G.F., Willis D.W., Blackwell B.G. \& Hubers M.J. (2002) Influence of a saugeye introduction program on the black crappie population in Richmond Lake, South Dakota. North American Journal of Fisheries Management 22, 1416-1424.

Ground T.A. \& Groeger A.W. (1994) Chemical classification and trophic characteristics of Texas reservoirs. Lake and Reservoir Management 10, 189-201.

Guest W.C., Drenner R.W., Threlkeld S.T., Martin F.D. \& Smith J.D. (1990) Effects of gizzard shad and threadfin shad on zooplankton and young-of-year white crappie production. Transactions of the American Fisheries Society 119, 529-536.

Guy C.S. \& Willis D.W. (1995) Population characteristics of black crappies in South Dakota waters: a case for ecosystem-specific management. North American Journal of Fisheries Management 15, 754-765.

Hale R.S., Lundquist M.E., Miller R.L. \& Petering R.W. (1999) Evaluation of a 254-mm minimum length limit on crappies in Delaware Reservoir, Ohio. North American Journal of Fisheries Management 19, 804-814.

Hayward R.S. \& Arnold E. (1996) Temperature dependence of maximum daily consumption in white crappie: implications for fisheries management. Transactions of the American Fisheries Society 125, 132-138.

Jenkins R.M. \& Morais D.I. (1971) Reservoir sport fishery effort and harvest in relation to environmental variables. In: G.E. Hall (ed.) Reservoir Fisheries and Limnology. Bethesda, MD: American Fisheries Society, Special Publication Number 8, pp. 371-384.

Le Cren E.D. (1958) Observations on the growth of perch (Perca fluviatilis L.) over twenty-two years with special reference to the effects of temperature and changes in population density. Journal of Animal Ecology 27, 287334.

Lee D.S., Gilbert C.R., Hocutt C.H., Jenkins R.E., McAllister D.E. \& Stauffer J.R. Jr. (1980) Atlas of North American Freshwater Fishes. Raleigh, NC: North Carolina State Museum of Natural History, 867 pp.
McInerny M.C. \& Cross T.K. (1999) Effects of lake productivity, climate warming, and intraspecific density on growth and growth patterns of black crappie in southern Minnesota lakes. Journal of Freshwater Ecology 14, 255264.

Maceina M.J. \& Stimpert M.R. (1998) Relations between reservoir hydrology and crappie recruitment in Alabama. North American Journal of Fisheries Management 18, 104 113.

Miller R.G. Jr. (1981) Simultaneous Statistical Inference, 2nd edn. New York: Springer-Verlag, 299 pp.

Miranda L.E. \& Durocher P.P. (1986) Effects of environmental factors on growth of largemouth bass in Texas reservoirs. In: G.E. Hall \& M.J. Van Den Avyle (eds) Reservoir Fisheries Management: Strategies for the 80's. Bethesda, MD: American Fisheries Society, Southern Division, Reservoir Committee, pp. 115-121.

Mitzner L.R. (1981) Influence of floodwater storage on abundance of juvenile crappie and subsequent harvest at Lake Rathbun, Iowa. North American Journal of Fisheries Management 1, 45-50.

Mitzner L.R. (1984) Crappie management: problems and solutions. North American Journal of Fisheries Management 4, 339-340.

Mitzner L.R. (1991) Effect of environmental variables upon crappie young, year-class strength, and the sport fishery. North American Journal of Fisheries Management 11, 534 542.

Muoneke M.I. (1994) Dynamics of a heavily exploited Texas white bass population. North American Journal of Fisheries Management 14, 415-422.

Oglesby R.T. (1977) Relationships of fish yield to lake phytoplankton standing crop, production, and morphoedaphic factors. Journal of the Fisheries Research Board of Canada 34, 2271-2279.

Pine W.E. III \& Allen M.S. (2001) Differential growth and survival of weekly age- 0 black crappie cohorts in a Florida lake. Transactions of the American Fisheries Society 130, 80-91.

Pope K.L. \& DeVries D.R. (1994) Interactions between larval white crappie and gizzard shad: quantifying mechanisms in small ponds. Transactions of the American Fisheries Society 123, 975-987.

Pope K.L. \& Willis D.W. (1998) Early life history and recruitment of black crappie (Pomoxis nigromaculatus) in two South Dakota waters. Ecology of Freshwater Fish 7, $56-68$.

Pope K.L., Willis D.W. \& Lucchesi D.O. (1996) Differential relations of age-0 black crappie and yellow perch to climatological variables in a natural lake. Journal of Freshwater Ecology 11, 345-350.

Ramos M.G. (1995) The Texas Almanac. Dallas: A. H. Belo Corporation, $672 \mathrm{pp}$. 
Rice W.R. (1989) Analyzing tables of statistical tests. Evolution 43, 223-225.

Ryder R.A. (1965) A method for estimating the potential fish production of north-temperate lakes. Transactions of the American Fisheries Society 94, 214-218.

Sammons S.M., Bettoli P.J. \& Greear V.A. (2001) Early life characteristics of age-0 white crappies in response to hydrology and zooplankton densities in Normandy Reservoir, Tennessee. Transactions of the American Fisheries Society 130, 442-449.

Schoffman R.J. (1965) Age and rate of growth of the white crappie in Reelfoot Lake, Tennessee, for 1959 and 1964 Journal of the Tennessee Academy of Science 40, 6-8.

Siefert R.E. (1968) Reproductive behavior, incubation and mortality of eggs, and postlarval food selection in the white crappie. Transactions of the American Fisheries Society 97, 252-259.

Summers G.L., Boxrucker J. \& Gabelhouse D.W. Jr. (1994) Introduction of saugeye to control overcrowded crappie populations. Transactions of the North American Wildife and Natural Resources Conference 59, 274-280.

Tomcko C.M. \& Pierce R.B. (2001) The relationship of bluegill growth, lake morphometry, and water quality in Minnesota. Transactions of the American Fisheries Society 130, 317-321.

Walters C.J. \& Post J.R. (1993) Density-dependent growth and competitive asymmetries in size-structured fish populations: a theoretical model and recommendations for field experiments. Transactions of the American Fisheries Society 122, 34-45.

Webb M.A. \& Ott R.A. Jr. (1991) Effects of length and bag limits on population structure and harvest of white crappies in three Texas reservoirs. North American Journal of Fisheries Management 11, 614-622.

Wilde G.R. \& Muoneke M.I. (2001) Climate-related and morphoedaphic correlates of growth in white bass. Journal of Fish Biology 58, 453-461. 